\title{
AN IMPACT OF THERMODYNAMIC PROCESSES IN HUMAN BODIES ON PERFORMANCE RELIABILITY OF INDIVIDUALS
}

\section{WPLYW PROCESÓW TERMODYNAMICZNYCH W ORGANIZMIE CZLOWIEKA NA JEGO SPOLEGLIWOŚĆ}

\author{
Zbigniew Smalko \\ Air Force Institute of Technology Warsaw, Poland \\ e-mail: zbigniew.smalko@itwl.pl
}

\begin{abstract}
The article presents the problem of the influence of thermodynamic factors on human fallibility in different zones of thermal discomfort. Describes the processes of energy in the human body. Been given a formal description of the energy balance of the human body thermoregulation. Pointed to human reactions to temperature changes of internal and external environment, including reactions associated with exercise. The methodology to estimate and determine the reliability of indicators of human basal acting in different zones of thermal discomfort. The significant effect of thermodynamic factors on the reliability and security of person.
\end{abstract}

Keywords: performance reliability, antropotechnical system, thermodynamic processes

Streszczenie. $W$ artykule przedstawiono problematykę wplywu czynników termodynamicznych na zawodność czlowieka $w$ różnych strefach dyskomfortu termicznego. Opisano procesy przemian energetycznych $w$ organizmie człowieka. Podano formalny opis bilansu energetycznego termoregulacji organizmu człowieka. Wskazano na reakcje czlowieka na zmiany temperatury wewnętrznego $i$ zewnętrznego otoczenia, $w$ tym reakcje zwiqzane $z$ wysitkiem fizycznym. Przedstawiono metodyke oszacowania i określenia podstawnych wskaźników niezawodnościowych człowieka działającego $w$ różnych strefach dyskomfortu termicznego. Wykazano istotny wplyw czynników termodynamicznych na niezawodność i bezpieczność człowieka.

Stowa kluczowe: spolegliwość, układ antropotechniczny, procesy termodynamiczne 
An impact of thermodynamic processes in human bodies on performance reliability..

Wplyw procesów termodynamicznych $w$ organizmie człowieka...

\section{Introduction}

Human beings perform their jobs that contribute to economic activities of societies and represent one component of the system that also incorporates various technical means. Humans are subjected to the impact of many factors associated both with technical means in use and perceived from the environment in very general meaning. These factors determine human ability to work, i.e. to interact with technical facilities that serve as working tools.

Numerous environmental factors that affect human organisms include climatic conditions that are really essential for individuals. These factors change their intensity and directions of impact but affect continuously human beings and definitely may be detrimental to the antropotechnical system made up of individuals and technical facilities and substantially contribute to ability of humans to perform their tasks in a safe manner.

Awareness of issues related to the impact of climatic factors onto the conduct of thermodynamic processes in human organisms, ability of the body to autonomously control its temperature and to adapt to ambient conditions in a reasonable manner can help on deployment of measures that counteract side and adverse effects of climatic factors onto the antropotechnical system. It is the approach that is in line with the natural struggling to diminish physiological load from work and improve accuracy of performed actions, productivity of work and safety of the antropotechnical system. It is the problem that cannot be resolved solely by technical disciplines since it needs comprehensive knowledge, experience and broad understanding of the entire system. Not only professional experience is necessary but also a kind of imagination combined with deep knowledge of human behaviour and interrelationships between technical and environmental factors.

Further considerations shall chiefly relate to an individual that exists in the system that is depicted in Fig. 1 and comprises a human being (C) and a technical objects (OT), confined surroundings - e.g. a cockpit or inner board (OW), external surroundings (OZ) and a control device (UR).

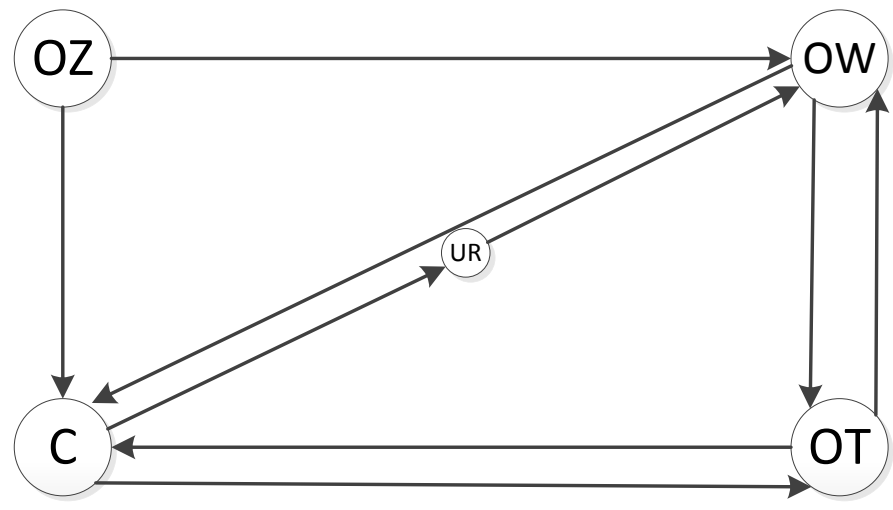

Fig. 1 The relationships between a human and its surroundings [14] 
The diagram in Fig. 1 depicts the most important interactions between the system components with the assumption that a human is able to affect the confined (near) surroundings (OW) by means of control devices (UR).

According to Klonowicz at al. [5], the set of factors that determine microclimate within the confined surroundings (OW) comprises three key groups:

1) exogenous factors (microclimatic and weather ones),

2) endogenous factors (related to operation of sanitary and technical equipment, nature and intensity of performed jobs, characteristics of the technological process, etc.),

3) propriogenous factors (determined by properties of materials that are applied to make separating surfaces to isolate a confined space with a specific microclimate from the ambient environment as well as by properties of the human clothes).

All climatic factors that act as psychical and physical stimuli can be split into three groups due to the impact nature:

1) meteorological factors that affect through the skin (temperature, humidity, air circulation, precipitation, sun illumination, other radiation types),

2) external factors that penetrate through the respiratory tract (temperature, airflow velocity and air pressure, content of nitrogen and other biologically active factors,

3) factors that affect sense receptors (organ of vision: sun illumination, cloudiness, fogs, weather maps; organ of hearing: sound of storms, voice weather messages, rustle of wind, etc.).

The factors of the third group are chiefly of psychological importance. The second group brings together issues that seem to only negligibly affect physiological processes of human organisms whilst the important impacts are included into the first group.

For warm-blooded organisms, such as human beings, thermal homeostasis (self-adjustment) is one of the factors that are indispensable to maintain correct progress of metabolic (energy conversions) processes. Keeping the body temperature constant is feasible owing to the mechanism of organism thermal control that adjusts the amount of heat to be dissipated by the body (physical thermal control) and generated by the organism (chemical thermal control) to the needs of thermal balance in warm or cold environment. Hence, thermal control of a human being is one of the components that contribute to the homeostasis process and make it possible to maintain constant parameters of the internal environment inside the organism. Heat generation is never uniform across the entire organism, since metabolism increases in pace with any physical effort and amount of heat dissipated by the body is then higher. That heat is referred to as the own or endogenous (internal) heat. It is heat that is identical to the one that is received from extracorporeal sources that is referred to as exogenous heat and can be supplied by both natural and technological resources. 


\section{Model of energy conversion inside a human body}

Any human organism should be considered as an open warm-blooded system that needs permanent supply of energy to maintain its desired physical and psychological constitution. The energy that is necessary for it is delivered along with food in the form or energy-rich compounds that release energy during the oxidation process. According to Krause [8], all the conversions inside the human organism take place with generation of heat. The model of energy conversion inside a human body is depicted in Fig. 2.

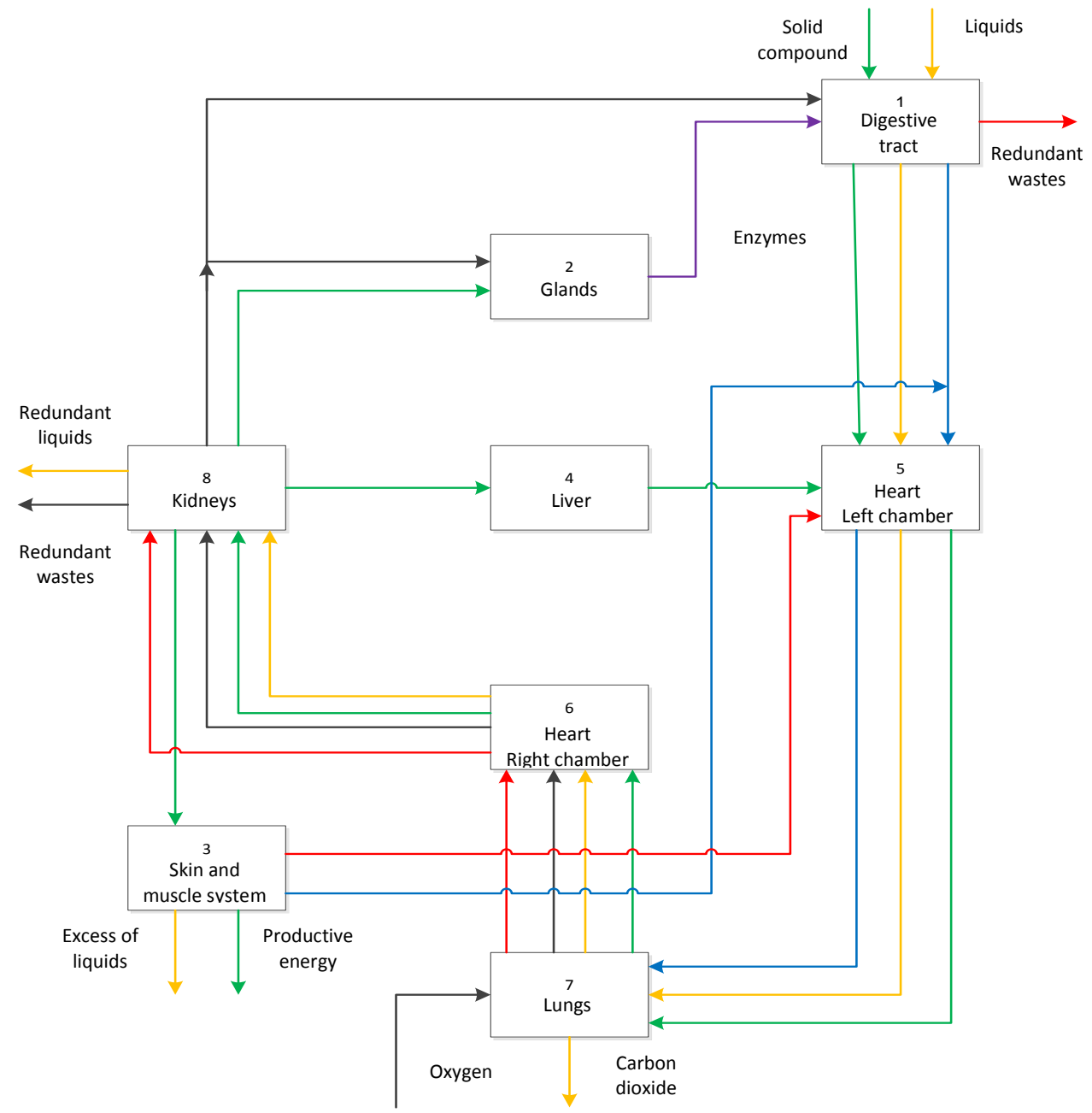

Fig. 2 Model of energy conversion in a human organism [14]

Obviously, like each model, a rough approximation that takes account of merely key organs, components and processes in such a sophisticated system as a human organism. However, illustration of that model may help to understand the thermal control (thermotaxis) model for a human organism. 
Individual boxes in Fig. 2 have the following meaning:

1 - Digestive tract,

2 - Glands that release hormones and enzymes,

3 - Muscles and skin,

4 - Liver (as a filter and the central source of heat),

5 - Heart - left-hand side,

6 - Heart - right-hand side,

7 - lungs,

8 - kidneys (as a filter).

From the point of thermodynamics, a human organism can be considered as a kind of engine. According to Krause [8], it needs to supply specific fuel types similarly to technological driving system. It is food that includes hydrocarbons, proteins and fats. The digestive tract (1) is externally supplied with food (energy sources) in the solid and liquid forms as well as enzymes provided by glands (2) and necessary for digestion. Harmful and waste product of metabolism in solid and liquid forms are removed outside, whilst productive metabolism compounds are transferred with blood via the left chamber (5) of heart to lungs (7). Lungs are also externally supplied with oxygen and discharge carbon dioxide and steam. Then blood with oxygen and nutritious components passes the right chamber (6) of the heart to kidneys (8) where harmful matters and excess of liquid is removed outside and then is supplied to muscles and skin that are represented by the box (3). Here nutritious components are converted into energy that is released in the form of muscle operation and of heat as well as some liquid is removed in the form of sweat. Blood with harmful admixtures that are released from metabolic processes is fed back to the left chamber of the heart. A portion of blood from kidneys (8) is supplied to the digestive tract (1) to be repeatedly enriched with products of digestions and a portion is branched to glands (2) where enzymes are produced. Possible excess of nutritious substances conveyed by blood can be stored in dedicated cells of liver (4) to be sourced, whenever necessary, from these cells and injected to the blood circulation. Generation of heat is never uniform for the entire body, some organs release more and some less heat. The amount of dissipated heat also depends on circumstances where a human being acts. During physical efforts metabolic processes (conversion of nutritious matters into energy) become more intense and amount of released heat increases. The metabolism needs involvement of specific catalytic agents that are referred to as enzymes. Basically, the degree of enzyme activity is a function of tissue temperature. When the body temperature drops or increases outside the permissible range (several centigrade degrees) the enzymes no longer act correctly, which leads to metabolism disturbances. It is why the body temperature, i.e. the balance between the released heat and its dissipation to the ambient environment must be relatively constant. Good or bad mood of an individual in the sense of thermal comfort depends on internal temperature of the body. One has to be aware that for each live organism its metabolic functions is so strongly coupled with the body structure that any discontinuity of metabolism immediately leads to structural disintegration. To keep the organism alive there is a kind of threshold level that is the absolute minimum for the metabolic processes that they can never be slowed down any more. That threshold is referred 
An impact of thermodynamic processes in human bodies on performance reliability..

Wplyw procesów termodynamicznych $w$ organizmie człowieka...

to as the Basal Metabolism Rate (BMR). According to Krause [8], drop of metabolism efficiency below that threshold may even lead to demise.

\section{Energy balance for a human body}

If a human body is considered as a detached system it is possible to make assumption that the law of energy conservation applies to it. No energy within the detached system can be generated or can disappear. Energy can be only converted from one form to another. Consequently, the balance between release of heat and its dissipation to the ambient environment should be relatively constant. Exchange of heat between the surface of the human body and the ambient environment, most frequently ambient air, is a sophisticated phenomenon that comprises four processes. Three of them are referred to as dry exchange include conduction, convection and radiation. The fourth one consists of perspiration and evaporation of sweat from the skin surface. The thermal balance is the basic term that is indispensable to understand the process of heat exchange between a human body and its ambient environment. According to Klonowicz et al., his methods for calculation of the thermal balance for a human body can be based on the following formula:

$$
\pm q=q_{m} \pm q_{r} \pm q_{c}-q_{e}=[\mathrm{kcal} / \mathrm{min}]
$$

where the individual symbols stand for:

$q$ - flux of heat exchanged between a body and its ambient environment,

$q_{m}-$ flux of heat generated by metabolic processes (energy expenditure),

$q_{r}-$ flux of heat exchanged by radiation,

$q_{c}$ - flux of heat exchanged by convections,

$q_{e}-$ flux of heat dissipated by evaporation.

The formula neglects the amount of heat that the organism receives from or dissipates to the ambient environment by conduction as well as heat that is disposed by discharge of steam contained in expired air since these both amounts are insignificant.

Obviously, the $q_{r}$ and $q_{c}$ parameters in the formula (1) can be both positive and negative depending on the direction of heat exchange.

The energy balance is in the state of equilibrium when discharge of heat $q_{m}$ inside the body is equal to its dissipation by radiation, convection and evaporation:

$$
q=q_{c}+q_{e}=[\mathrm{kcal} / \mathrm{min}]
$$

When the amount of $q$ is above or below zero, the respective phenomena of human body overheating or overcooling occur.

There are a number of methods that are available to determine individual components that make up the energy balance of an organism. Very strict determination of them is usually too sophisticated and impractical, in particular with regard to the amount of $q_{m}$, therefore empirical approximations are frequently employed instead.

For instance, one example of such method for determination of energy expenditure $q_{m}$ is provided below along with the related Table 1 


$$
q_{r}+q_{c}=\frac{1}{0,61\left(\frac{\vartheta}{289}\right)^{3}+0,19 V^{0,5}\left(\frac{298}{\vartheta}\right)^{3}}[\mathrm{kcal} / \mathrm{min}]
$$

where:

$\vartheta$ - temperature of ambient environment in the absolute scale,

$\mathrm{V}-$ velocity of air flow $[\mathrm{m} / \mathrm{s}]$,

$\mathrm{m}$ - rate of heat conversion processes $[\mathrm{q} / \mathrm{min}]$

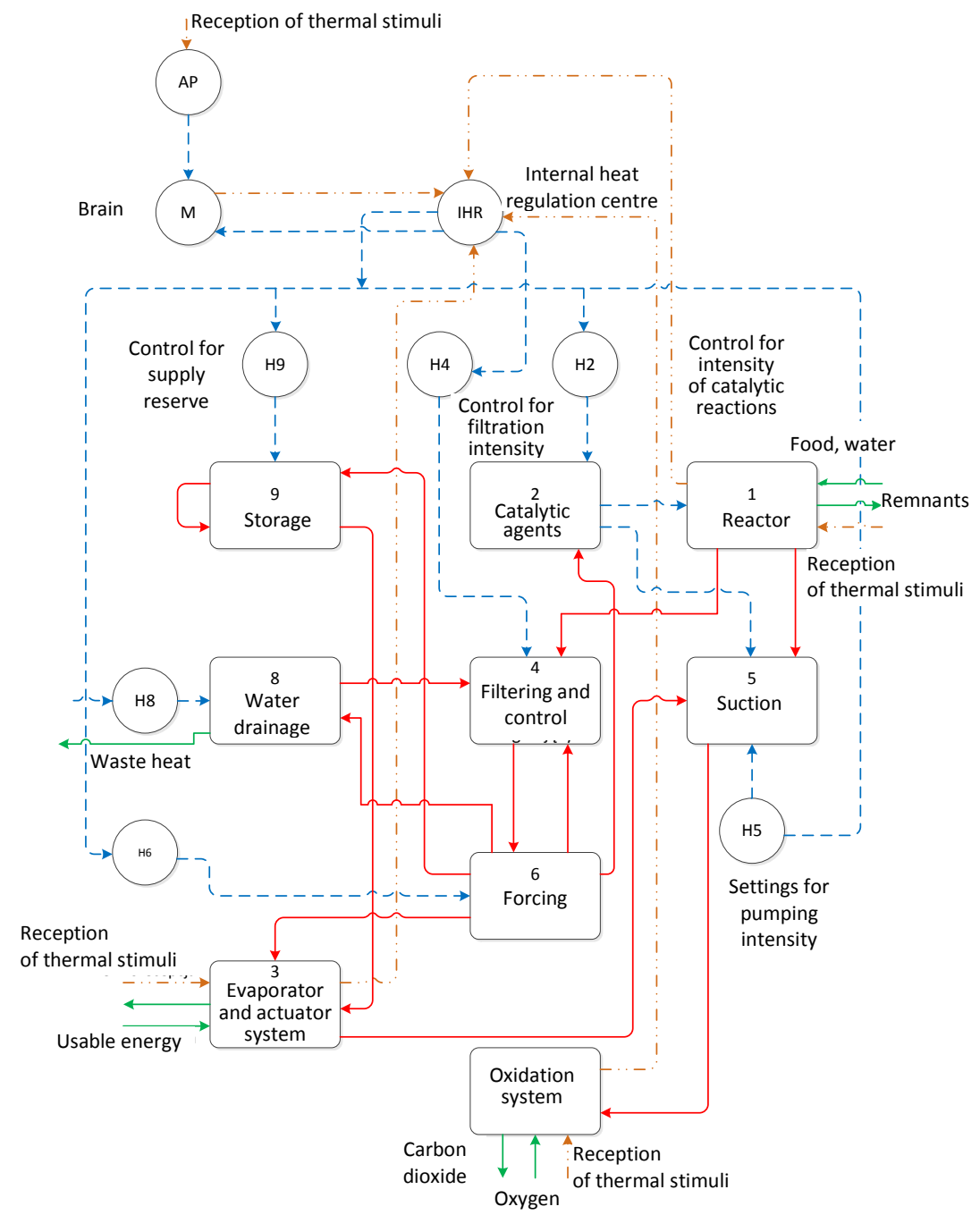

Fig. 3 The model for the thermal control system of a human body [14] 


\section{Description of the thermal control system for a human body}

When the amount of heat flux exchanged between a body and its ambient environment is different from zero it means that the body is either overheated or overcooled. Thus, when the temperature of the body and /or the environment is subject to changes the thermal control system must be triggered to adapt the organism and restore the state of thermal equilibrium.

The model for the thermal control system of a human body is shown in Fig. 3. Individual boxes are marked in the same way as in Fig. 2 but some organs are provided with adjusting controls that are denoted with the same numbers.

The following additional acronyms are applied:

AP - measuring (sensing) equipment,

$\mathrm{M}$ - brain,

IHR - internal heat regulation centre.

The thermal control system incorporates:

- thermal reception components (to receive thermal stimuli)

- thermal control centres,

- actuators of the system (to effect the adjustments).

A human organism by means of receptors that are deployed in human skin and sense heat or cold receives thermal stimuli. They are then connected with thermal detectors of the central neural system. Similar thermal receptors, though of less importance, are located in muscles, deep venal nodes and in the respiratory tract.

Thermal receptors embedded into human skin split into two types: the ones that are sensitive exclusively to cold and the ones, less numerous, that are sensitive exclusively to heat. The map of points sensitive to cold and heat is different for various areas of skin. Each square centimetre of the forelimb skin comprises from 13 to 16 points of cold and 1 to 3 points of hot sensing. Nearby the thermal control centre located in the hypothalamus of the brain there are thermal detectors that react to the temperature of the thermal control centre. Thermal control centre lies in the front, rear part of the hypothalamus, and is split, in the terms of functionalities, into two parts: the front portion of the hypothalamus is sensitive to temperature growth within the human body so that to protect the organism against overheating. The rear portion of the thermal control centre is the organ that struggles to keep the body warm, thus it is sensitive to cooling of the organism. The neural structure that is referred to as the thermal control centre is responsible for setting the appropriate temperature and taking the decision about necessary measures that are aimed at increasing or decreasing the body warmth. In case of specific and undesired alterations, the natural response of each organism consists in elevation of its temperature. The thermal control system elevates the set point for the temperature and the organism starts tending to reach the equilibrium state at the new and higher 
set point. It is continued until the organism reached the temperature determined by the thermal control system. Under very specific circumstances the thermal control centre changes the thermal set point to a higher level that leads to elevated temperature of the entire organism. Upon the set point is altered, the organism starts intense generation of heat and undertakes preventive measures to avoid its dissipation. The process is carried on until the temperature reaches the new set point.

\section{Formal description of the process of thermal control for a human body}

According to Hammel [3], the temperature control centre that adjusts internal temperature of a human body operated according to the principle of a proportional regulator. It means that the level of signals that are sent to actuating controls (thermal control reaction) is directly proportional to the differential temperature between the present (reference) value and the actual one. It is assumed that the level of reference temperature is the temperature of the hypothalamus. It is very similar to technical systems where the thermal control is based on a tracking system that adjusts the actuators to a reference set point (the required level of controlled temperature that should be maintained by the tracking system). The reference level can be temporary constant or may subject to variations in time. According to Klonowicz et al., in case of a system with continuous proportional control the adjusting signal can be described by the following formula:

$$
Y_{t}-Y_{0}=\alpha\left(\vartheta-\vartheta_{0}\right)
$$

where:

$$
\begin{aligned}
& Y_{t}-Y_{0}-\text { stands for the thermal control response (metabolic heat, the vascular } \\
& Y_{0} \quad-\text { reference (typical) intensity of the foregoing functions, } \\
& \vartheta_{0} \quad-\text { differential temperature between the actual value and reference } \\
& \vartheta \quad-\quad \text { current temperature of the hypothalamus (the feedback signal) } \\
& \vartheta_{0} \quad-\text { operational set point for the considered type of thermal control } \\
& \text { response (may subject to variations) } \\
& \alpha \quad-\text { factor of proportionality. }
\end{aligned}
$$

It was also found out that the set point, i.e. the reference temperature that occurs in the formula (3) is not a constant parameter but it may subject to variations within certain limit, depending on current circumstances.

Besides controlling the internal temperature of a human body pursuant to the rule of continuous proportional adjustment, the thermal control mechanisms sometimes 
demonstrate the properties of binary (threshold) control according to the ON-OFF principle.

In case of the binary (threshold) control the adjustment signal can be described by means of the following formula:

$$
\begin{array}{ll}
\text { for } \vartheta<\vartheta_{0}, & Y_{t}=Y_{\max } \\
\text { for } \vartheta>\vartheta_{0}, & Y_{t}=0
\end{array}
$$

where:

$Y_{t}$ - output signal for the thermal control mechanism,

$Y_{\max }-$ maximum output signal for the thermal control mechanism.

In case of the follow-up (tracking) proportional control the thermal control response subjects to the operation principle of the PD (proportional-derivative) controller, i.e. the amount of control signal is proportional to the ramp rate of temperature changes, which can be expressed by the following equation:

$$
Y_{t}-Y_{0}=\gamma \frac{d \vartheta}{d t}
$$

where:

$$
\begin{array}{ll}
\gamma & - \text { factor of proportionality; } \\
\frac{d \vartheta}{d t}- & \text { ramp rate of temperature. }
\end{array}
$$

Results from the completed investigations of the thermal control system indicate that all three foregoing control mechanisms coexist in the investigated system.

\section{Responses to variations of the ambient temperature}

The temperature of thermal comfort is sensed when a human being feels neither excessive heat nor cold. When the temperature exceeds the comfort interval the effect of overheating occurs, otherwise the overcooling effect may lead even to hypothermia (Krause [8], Walentin [11]).

Overall alterations that occur as the effect of extreme overheating of a human body are referred to as hyperthermia that is understood as overheating, i.e. the organism constitution when the ambient temperature exceed the interval of thermal comfort and excessive head must be evacuated outside the organism. Adaptation of the heat evacuation from the organism to the needs of thermal equilibrium is carried out by changes of blood circulation in capillary vessels of skin, secretion of sweat and, in some less degree, by changes in ventilation of lungs. Heat dissipation at excessive temperature is carried out in both the passive manner (radiation, conduction and convection) and in active way (evaporation of sweat). When the ambient 
temperature exceeds 28 to $32^{\circ} \mathrm{C}$ thermal control secretion of sweat occurs. The more intense thermal load affects the organism the higher number of sweat glands is triggered to the active state. At very heavy physical work at high temperatures, the amount of sweat secretion may reach even up to 3 to 4 litres per hour. Anyway, high ambient temperature may lead to thermal fainting, cramps, exhaustion and thermal shock.

Overall alterations that take place when an organism has been extremely cooled down are referred to as hypothermia. It is that is understood as overcooling, i.e. the organism constitution when the temperature of the body drops down below $35^{\circ} \mathrm{C}$. Hypothermia is caused by too fast cooling down of the organism as compared to its ability to generate heat. The most frequent reason for that phenomenon it is the effect of cold air and, what is more hazardous of cold water. Another reason for hypothermia can lie in disturbances of metabolic processes. When the ambient temperature is lower than the interval of thermal comfort the body must speed up generation of heat. The hazard of alterations caused by the effect of cold temperatures depends on the rate how much heat is being lost by conduction and radiation (that is proportional to the differential warmth between the body and the ambient environment). Low temperature of ambient air, in particular combined with strong wind is also the impact that contributes to overcooling of an organism. However, water is able to convey heat much better than air and a human body can be cooled down even 20 times faster. Consequently, no organism is able to compensate such huge loss of heat. In water at the temperature below $10^{\circ} \mathrm{C}$ a human being is able to survive as long as the actual water temperature is. It is assumed that extreme hypothermia of the organism takes place when an individual stays in cold water longer than 10 to 15 minutes.

\section{Human body responses associated with physical efforts}

During any physical work, about 70 to $80 \%$ of the entire expenditure of energy is released in the form of heat. When the work is carried out in a chill ambient environment all excessive heat is evacuated from the organism and the equilibrium of thermal balance is preserved. In a hot ambient environment, the thermal control efficiency of a human body may prove insufficient since the only way to dissipate heat from the organism consists in evaporation of sweat. At very high humidity of ambient air the organism may secrete sweat at really high amounts but sweat is incapable of evaporating and the desired effect of heat dissipation cannot be accomplished. Approximate values of energy expenditure $q_{m}$ in $[\mathrm{kcal} / \mathrm{min}]$ depending on the type of work /acc. to N. K. Witte [15]

Heat is accumulated in an organism and the body temperature keeps growing. Any physical efforts always lead to increase of the internal temperature of a human body, regardless the circumstances, i.e. whether the work is carried out at hot or 
An impact of thermodynamic processes in human bodies on performance reliability..

Wplyw procesów termodynamicznych $w$ organizmie człowieka...

cold ambient environment. Although for the latter case, it is theoretically possible to evacuate excessive heat to the surroundings but the internal temperature of an organism essentially increases during initial 30 to 40 minutes and then stabilizes at the level that exceeds the resting temperature, and correlated with the work intensity.

\section{Table 1}

\begin{tabular}{|l|c|}
\hline Work type & $\begin{array}{c}\text { Energy } \\
\text { expenditure } \\
{[\mathrm{kcal} / \mathrm{min}]}\end{array}$ \\
\hline No physical load, light desk job & $1.2-1.5$ \\
Light physical work, mainly sedentary (HR of 80 to 90) & $2.0-3.0$ \\
Moderate physical work, (HR of 90 to 110) & $3.5-4.5$ \\
Heavy physical work (HR of 130 to 150) & $5.6-7.0$ \\
Extremely heavy physical work (HR above 150) & $8.0-9.0$ \\
\hline
\end{tabular}

At the moment when and individual commences physical activities the metabolism of the body increases and the body temperature at the elevated level is controlled more accurately than at the resting level. Thus, increase of the body temperature during any physical work is the consequence that the thermal control system of a human body is not failed. Even the contrary - such a phenomenon can be beneficial since the temperature gradient between the body interior and its surface increases that facilitates conduction of heat from internal organs where heat is generated to the body surface where it can be readily dissipated to the ambient environment.

Operation of the thermal control system at work in the ambient environment with high temperature is really sophisticated. The work is associated with a series of problems, such as dehydration of the organism, dislocation of liquids in the organism, alterations in blood composition and disturbances in functioning of internal organs. If so happens it is necessary to support operation of the thermal self-control system with conscious measures intended to facilitate heat dissipation. However, excessive cooling is not a good way out since it may lead to hypothermia of human body and is hazardous for health. The technical solution that is nearly perfect is the air-conditioning system that is implemented in cabins of modern passenger aircrafts where separate, individually controlled airflow for each passenger.

When a human being that is the subject of the investigation performs heavy physical work, with high-energy expenditure, the heat that is released and accumulated in his body would lead to incomparable growth of the body temperature. If such, a temperature growth is associated with high ramp rates the circumstances become hazardous to human health or even life. 


\section{Quantitative estimation of factors that determine thermodynamic equilibrium of human body and their impact onto successful performance of a human being under variable climatic conditions}

The energy balance of a human organism depicts its general constitution with such factors as the overall time of work since prolonged work, with constant conditions for the work execution, inevitably lead to changes (drop) of the efficiency and performance of the human work.

In analytic manner that time can be calculated from the following relationship:

$$
t=\frac{q_{a}}{q}=\frac{q_{a}}{q_{m} \pm q_{r} \pm q_{c}-q_{e}}
$$

where:

$q_{a}$ - such amount of heat accumulated by a human body that leads to the growth of its temperature by a permissible limit $\Delta \vartheta \leq 1,1 K$,

On the basis of information available from the literature references [9] it is commonly assumed that the maximum amount of accumulated heat is $\left[q_{a}\right]=63$ kcal with the maximum amount of heat that can be dissipated by evaporation $\left[q_{a}\right]$ $=585 \mathrm{kcal} / \mathrm{h}$. These parameters served as the baseline to estimate selected factors for safety and reliable performance of a human being in various areas of thermal discomfort.

Table 2 Climatic zones according to Kriczagin [9]

\begin{tabular}{|c|c|c|c|c|}
\hline $\begin{array}{l}\text { Discomfort } \\
\text { degree }\end{array}$ & $\begin{array}{l}\text { Temperature } \\
\text { of the body } \\
\text { surface, }{ }^{\circ} \mathrm{C}\end{array}$ & $\begin{array}{l}\text { Flux of } \\
\text { accumulated } \\
\text { heat, kcal/h }\end{array}$ & $\begin{array}{l}\text { Flux of heat } \\
\text { dissipated by } \\
\text { evaporation, } \\
\mathrm{kcal} / \mathrm{h}\end{array}$ & Remarks \\
\hline III (very hot) & 36.6 & 100 & $(300,1200)$ & $\begin{array}{l}\text { Hazard to compensation } \\
\text { abilities and performance } \\
\text { of the self-control } \\
\text { mechanism }\end{array}$ \\
\hline II (hot) & $36 \pm 0,6$ & 80 & $(150,300)$ & \multirow{5}{*}{$\begin{array}{l}\text { Range for reliable } \\
\text { operation of the thermal } \\
\text { self-control mechanism }\end{array}$} \\
\hline I (warm) & $34.9 \pm 0.7$ & $(50,80)$ & $(35,150)$ & \\
\hline comfort & $33.2 \pm 1.0$ & \pm 25 & $\sim 30$ & \\
\hline I (chill) & $31.1 \pm 1.0$ & -80 & $<29$ & \\
\hline II (cold) & $29.1 \pm 1,0$ & $/-80,-160 /$ & - & \\
\hline III (very cold) & 28.1 & 180 & - & $\begin{array}{l}\text { Possible incapability of } \\
\text { keeping the body warm }\end{array}$ \\
\hline
\end{tabular}

The table above compiled on the basis of the available reference figures demonstrates that zones of thermal discomfort are correlated to the ability of human body to maintain the thermodynamic balance. 


\section{Evaluation of the error-free performance of humans in thermodynamic environments}

Let us assume that the basic parameters of reliability $\lambda(t)$ stands for intensity of the fact that psychophysical performance of a human being has decreased and the function above can be considered as the function of the risk that a human performs inefficiently. The function is expressed as the conditional probability of the fact that the functional non-performance of a human being may really happen at the random moment of time $t$ provided that such an even has never happened beforehand. Let us also assume that the hypothesis on the exponential distribution of the probability for the time $T$ of reliable performance of a human being cannot be discarded for qualitative verification of the function for density of the probability that a human performs correctly. If so, the probability density for the $T$ variable can be expressed as below:

$$
f(t)=\frac{1}{2 \bar{T}},
$$

where: $\bar{T}$ - an expected value of reliable performance of a human being.

The intensity of performance deterioration $\lambda(t)$ and expected residual time of faultfree operation Et of a human being can be described as below:

$$
\lambda(t)=\frac{1}{2 \bar{T}-t}, \quad E t=\frac{2 \bar{T}-t}{2}
$$

Since the asymmetry factor and the excess for the function depend on variations of the $\lambda$ parameter for the exponential distribution, the assumption can be adopted that the $\lambda$ parameter may depend on changes in the thermodynamic equilibrium between a human body and its ambient environment, i.e.

$$
\lambda=f\left(q_{e}, q_{m}, q_{r}, q_{c}\right)
$$

The average time of fault-free operation $\bar{T}$ and expected residual time of fault-free operation $E t$, the intensity of performance deterioration $\lambda$ of a human being in six zones of thermal discomfort are summarized in Table 3 below, where the average operational performance under the conditions of thermal comfort is assumed as the

\begin{tabular}{|c|c|c|c|c|c|c|}
\hline $\begin{array}{c}\text { Discomfort } \\
\text { degree }\end{array}$ & $\begin{array}{l}\text { I+l } \\
\text { III }\end{array}$ & $\begin{array}{c}1+1 \\
\text { II }\end{array}$ & $\begin{array}{c}\text { I+/ } \\
\mathrm{I}\end{array}$ & $\begin{array}{c}\text { I-I } \\
\text { I }\end{array}$ & $\begin{array}{c}\text { I-I } \\
\text { II }\end{array}$ & $\begin{array}{l}\text { I-I } \\
\text { III }\end{array}$ \\
\hline $\begin{array}{c}T_{a v}[h] \\
\lambda\end{array}$ & $\begin{array}{c}0.5 \\
2\end{array}$ & $\begin{array}{c}3 \\
0.333 .\end{array}$ & $\begin{array}{c}6.0 \\
0.166 .\end{array}$ & $\begin{array}{c}\sim 6.0 \\
0.166 .\end{array}$ & $\begin{array}{c}3.33 . . \\
0.3\end{array}$ & $\begin{array}{c}0.5 \\
2\end{array}$ \\
\hline
\end{tabular}
reference.

Table 3 
Functions: reliability $R(t)$, expected residual time of fault-free operation $E t$ and the intensity of performance deterioration $\lambda$ are plotted in Fig. 4, 5 and 6.

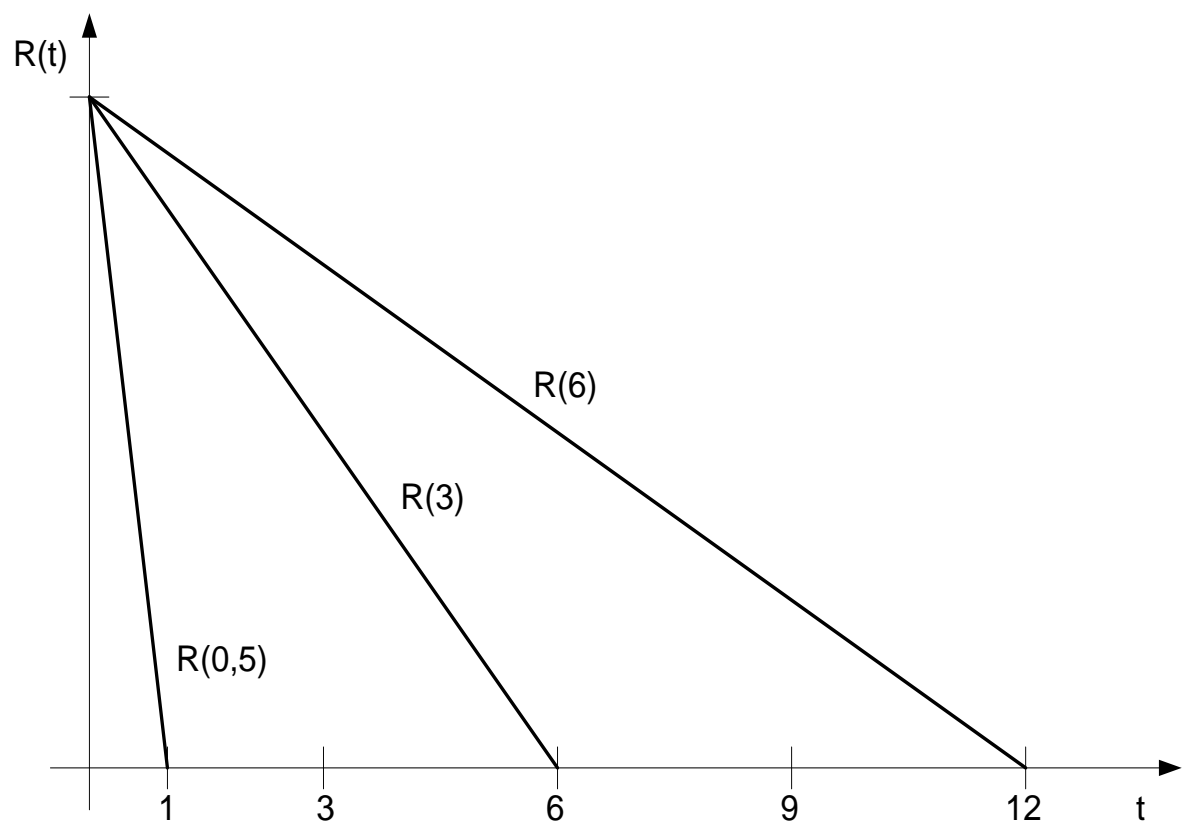

Fig. 4 Plots for the reliability (trustworthiness) functions

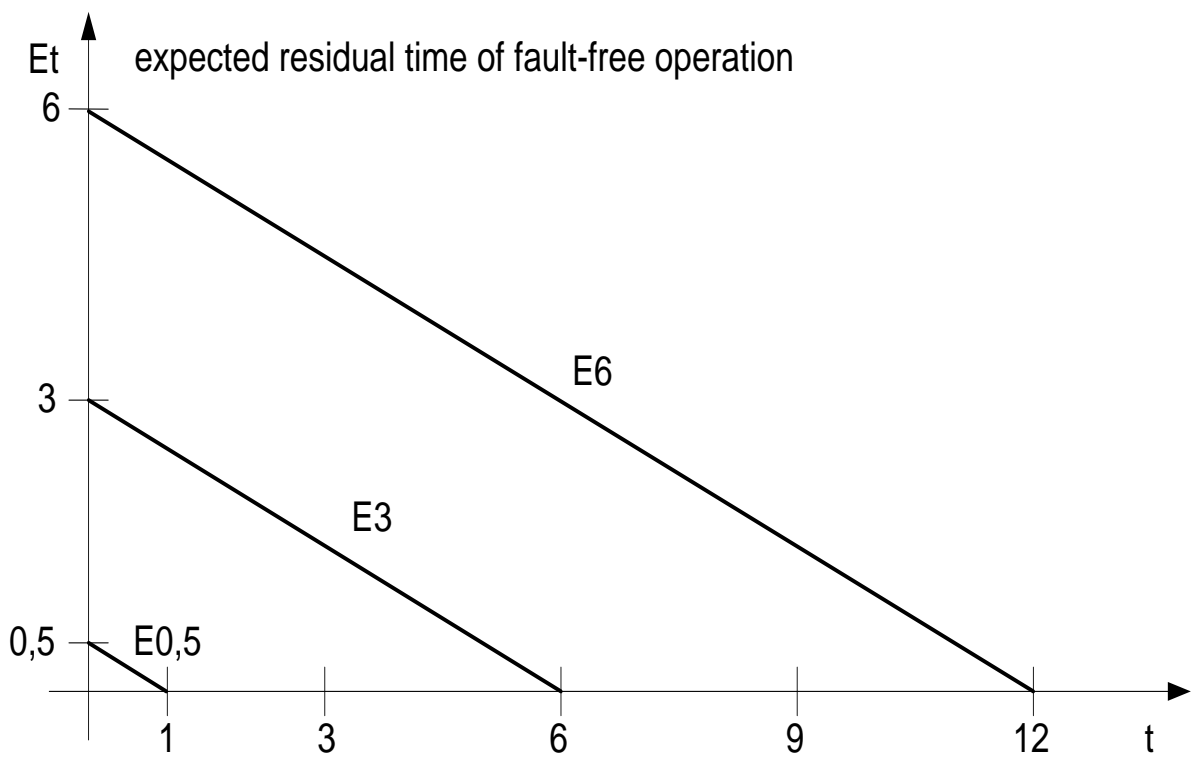

Fig. 5 Plots for the expected residual time of fault-free operation 


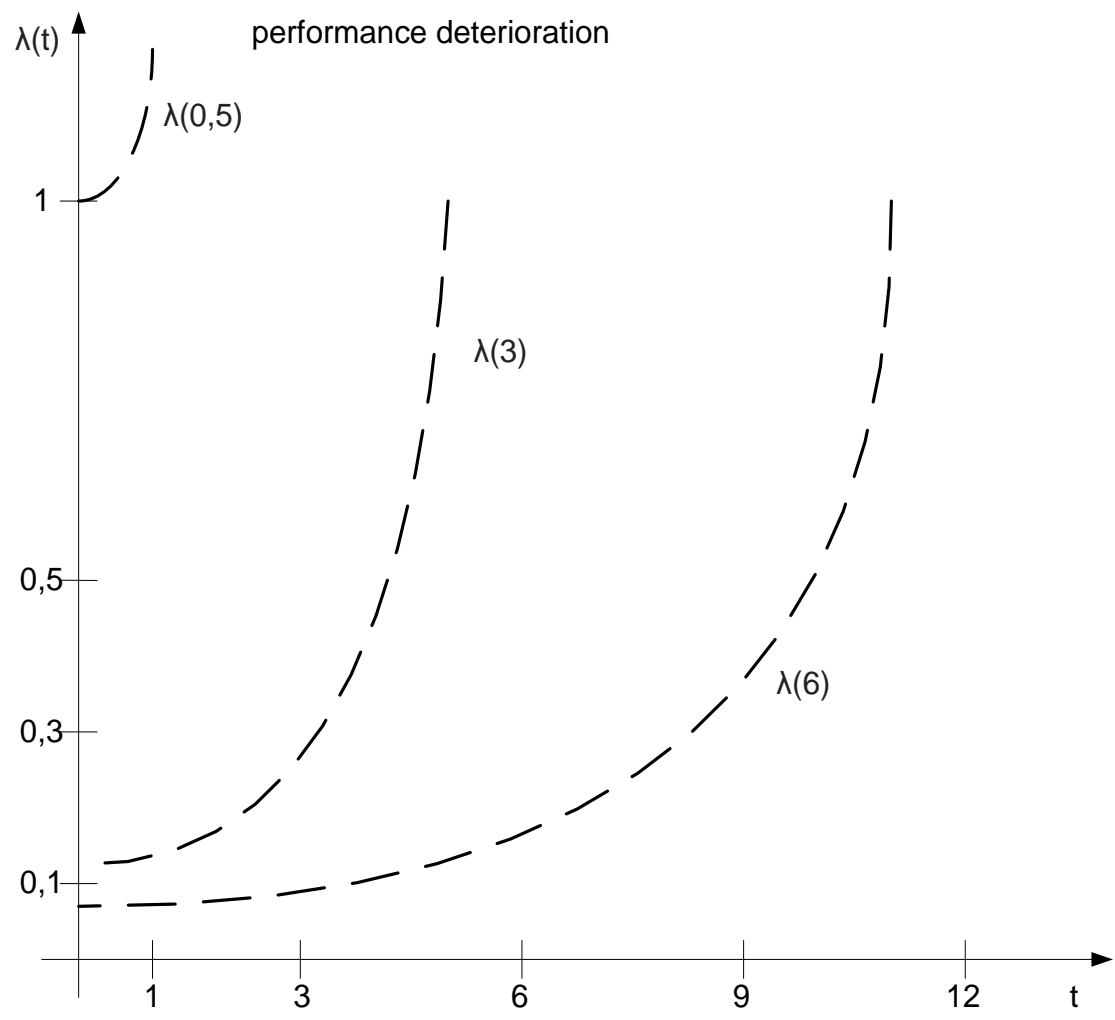

Fig. 6 Plots for the intensity of performance deterioration

\section{Conclusions}

Error-free performance of a human organism depends on a number of factors, including the energy balance that, in turn, is affected by climatic conditions of the ambient environment and intensity of the work to be performed.

Description of the models for conversion between various forms of energy and for thermal self-control of a human organism is intended to reveal a hypothetical qualitative relationships between the energy balance of a human body and the human ability to reliably (trustworthily) act under specific climatic conditions.

The completed analysis of reference resources results in the attempt to estimate variability of the reliability function, the intensity of performance deterioration and expected residual time of fault-free operation of a human being with regard to changes of microclimatic factors. 


\section{References}

[1] Bobrowski D.: Modele i metody matematyczne teorii niezawodności, WNT, Warszawa 1985 (Mathematic models and methods for the theory of reliability, WNT Publishing House, Warsaw, 1985)

[2] Fanger P.O.: Komfort cieplny: Wyd. Mady. Warszawa (Thermal comfort, Mady Publishing House, Warsaw),

[3] Hammel T.F.: Physiological Regulations, s.182, Philadelphia 1965

[4] ISO 7730:2006 (U) Ergonomia, środowisko termicznie umiarkowane. Analityczne wyznaczanie i interpretacja komfortu termicznego z zastosowaniem obliczania wskaźników PMV i PPD oraz kryteriów lokalnego komfortu termicznego. (Ergonomics of the thermal environment. Analytical determination and interpretation of thermal comfort using calculation of the PMV and PPD indices and local thermal comfort criteria).

[5] Klonowicz S., Kozłowski St.: Człowiek a środowisko termiczne, PZWS, Warszawa, 1970 (Human being and thermal environment, PZWS Publishing House, Warsaw, 1970).

[6] Koradecka D.: Bezpieczeństwo pracy i ergonomia. CIOP Warszawa 1999 (Occupational safety and ergonomics, Central Institute for Labour Protection, Warsaw, 1999).

[7] Kostyro K., Łobzowski A.: Klimat. Pomiar i regulacja. Agencja Wydawnicza RAK, Warszawa 2002 (Climate. Measurements and Control. RAK Publishing Agency, Warsaw, 2002).

[8] Krause M.: Ergonomia: praktyczna wiedza o pracującym człowieku i jego środowisku, Śląska Organizacja Techniczna. Katowice,1992 (Ergonomics: the practical knowledge about a working human and its environment, Silesian Technical Organization, Katowice, 1992).

[9] Кричагин В. И, Тепловой дискомфорт. Военно-Морской журнал, № 10.30. Ленинград, 1965 (Thermal discomfort, The Journal of Navy, No. 10, 30, Leningrad, 1965).

[10] Marszałek A., Softy Feto K. Człowiek w warunkach obciążenia termicznego. CIOP Warszawa 2001 (A human being under conditions of thermal load, Central Institute for Labour Protection, Warsaw, 1999).

[11] Walentin H. et al., Medycyna pracy, PZWL Warszawa 1985 (Occupational medicine, PZWL Publishing House, Warsaw, 1985).

[12] PN EN 27243:2005 Środowiska gorące. Wyznaczenie obciążenia termicznego działającego na człowieka podczas pracy, oparte na wskaźniku WBGT. (Hot environments. Estimation of the heat stress on working man, based on the WBGT-index (wet bulb globe temperature))

[13] PN EN ISO 7933:2005 (U) Ergonomia środowiska termicznego -Analityczne wyznaczanie i interpretacja stresu cieplnego $\mathrm{z}$ wykorzystaniem obliczeń przewidywanego obciążenia termicznego (Ergonomics of the thermal environment. Analytical determination and interpretation of heat stress using calculation of the predicted heat strain) 
An impact of thermodynamic processes in human bodies on performance reliability..

Wplyw procesów termodynamicznych $w$ organizmie człowieka...

[14] Smalko Z., Suprunowicz R., Radecki H.: Model wpływu procesów termodynamicznych $\mathrm{w}$ organizmie człowieka na jego niezawodność, Wydawnictwo O PT, Katowice 1979 (The model for impact of thermodynamic processes in human body onto its reliability, OPT Publishing House, Katowice, 1979).

[15] Витте Н.К.: Тепловой обмен человека и его гигиеническое значение. ИМЛ, Киев, 1956 (Heat exchange of a human body and its hygienic importance, IML, Kyiv, 1956)

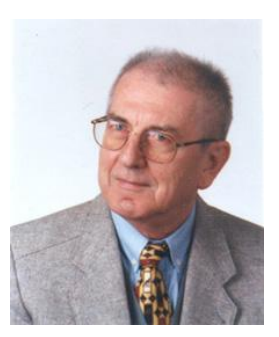

Prof. Zbigniew Smalko, DSc. PhD. Eng., professor in the Air Force Institute of Technology, Warsaw, as well as the Warsaw University of Technology, Faculty of Transport. Specialist in reliability safety and maintainability of technical transport systems, operation problems of transport systems and devices. Author and co-author of more than 200 scientific publications. Member of: Polish Academy of Science (PAN) - Transport Committee, PTBiN, ERN SAFERLENET, ETNiŚT; Editor in Chief of Archives of Transport, Chair of Winter Schools of Reliability PAN. An organiser and a member of several scientific and programme committees of international and national conferences and symposiums. 